\title{
Typing yourself accountable: \\ Objectifying subjective experiences in an online health forum
}

\author{
Elisabeth Muth Andersen (Odense)
}

\begin{abstract}
In this paper, I outline linguistic and discursive practices online forum participants use to make sense of painful and disturbing bodily experiences which from the participants' perspectives have not been explained, diagnosed and treated by medical professionals.

By scrutinizing a thread from a Danish online health forum on the topic metabolism using conversation analytic perspectives, I show that participants use practices that objectify their experiences when seeking support and recognition in the forum. Four practices for objectifying experiences understood as undiagnosed symptoms of illness are outlined: (1) Presentation of problem by presenting a medical history of symptom discovery; (2) Presentation of symptoms in a list using medical terms, extreme case formulations (Pomerantz 1986), and elliptic constructions; (3) Presentation of a candidate medical cause supported by evidence and sources; and (4) Presentation of objective facts and other sources as the expected solution. It is argued that the responses, characterized by agreement and tellings of similar stories, contribute to the objectification of subjective experiences by delivering perspectives that can be used as information sources and for experience based generalization.
\end{abstract}

\section{$1 \quad$ Introduction}

sufferers grab at cultural resources, assimilate them to their own state, recognize their failure, throw them off, and reach for more. They run through these things, using them up until they find themselves with no place to turn. They are falling out of culture.

(Hilbert 1984: 375)

People who persistently and recurrently experience bodily pain and disorders have a range of social practices in a society for dealing with these experiences. In western cultures, for example, people are expected to consult health professionals who will conduct medical examinations, make diagnostic claims, treatment recommendations, etc. (Heritage/Maynard 2006). In many cases, however, medical examinations do not straightforwardly lead to medical diagnosis, medical treatment, and a relief of pain. ${ }^{1}$ When pain and disturbances persist despite hav-

\footnotetext{
${ }^{1}$ It is assessed that 300'000 Danes are ill without having a medical diagnosis (Thorhauge 2015), and it is assessed that a significant number of Danes (10-30\%) who consult their GP have unspecific symptoms such as pain, fatigue, weakness and fear of disease (Kessing 2016).

Linguistik online 87, 8/17 - http://dx.doi.org/10.13092/lo.87.4172
}

CC by 3.0 
ing consulted health professionals and medical knowledge, sufferers are confronted with a range of emotional and social challenges in terms of how to deal with this reality.

In this paper, I investigate some of the ways that people who chronically experience bodily pain and disorders make sense of their experiences and attempt to (re-)gain social accountability. For this purpose, ordinary people's interactions in an online health forum on health ${ }^{2}$ will be analyzed, focusing on the practices used to make sense of experiences by objectifying them through linguistic, discursive and interactional practices. Accountability is a term used in ethnomethodology and conversation analysis (Antaki et al. 2005; Stommel 2009). In Harold Garfinkel's terms (1967: VII), members use methods for making their activities “"accountable', as organizations of commonplace everyday activities". Hence, accountability may be understood as intelligibility or explainability (ten Have 2005), i. e. methods for making actions understandable and recognizable to others. Ethnomethodologists theorize that social order is an accomplishment of members of society. It is "a single self-producing order" (Hilbert 1995: 164) consisting of accounting practices (Garfinkel 1967) rather than consisting of an objective reality and a normative order. Individuals, people, or so-called "members of society" (ten Have 2005) orient to social accountability in the conduct of everyday activities.

Even knowledge and facts are seen as social phenomena interwoven with social accountability:

the constraint imposed upon one's descriptive work does not derive from the objective ordering of the external universe, but rather from activities and responses of other people - in classic terms, the society. The uses of cultural resources in reality production are sanctioned by others in a society on the basis of such partially formulated folk-criteria as adequacy, correctness, reasonableness, and common usage. In short, not just any description is allowed to count as adequate. Individuals internalize social constraint, providing for the possibility of experiencing the adequacy of their accounts as arising from their correspondence to objective reality.

(Hilbert 1984: 374)

Social accountability has been described and documented empirically as something people orient to in everyday activities (Buttny 1993). Furthermore, phenomenologists and ethnomethodologists have described, investigated (Hilbert 1984) and conducted experiments of lack of social accountability (Garfinkel 1967), for example the experience of chronic pain. According to Hilbert (1984), chronic pain differs from normal pain because normal pain is expected to end within a reasonable period of time, which chronic pain is not. This alters the entire experience, especially the sufferer's conception of the affliction (Hilbert 1984). Folk theories or everyday understandings of pain include only normal pain, which means that people who experience chronic pain lack resources for making their experiences socially accountable. Further, pain is a private experience, which means that sufferers will not be able to get their experiences verified by others as an experience of objective internal reality (Hilbert 1984). In this paper, I outline linguistic, discursive, and interactional practices online forum participants use to make sense of painful and disturbing bodily experiences which from the participants' perspectives have not been explained, diagnosed and treated by medical professionals.

\footnotetext{
2 The health website in which the online forum under investigation is found was placed as the 16th most visited online publication in Denmark in September 2016 (Dansk Online Index 2016).
} 
For this purpose, I analyze one thread consisting of ten postings in an online health forum on metabolism. This thread is chosen as it exemplifies several recurrent practices of presenting and understanding problems and dealing with challenges concerning social accountability in the forum (Andersen 2015, in press). Analyses show that participants use a range of narrativelike practices to objectify experiences and thereby present them as undiagnosed symptoms of illness. Built into these practices are also indications that participants' understand the action of challenging medical professionals' authority as highly accountable. These indications also include strategies to strengthen claims and arguments.

By analyzing the first posting of the tread in more detail, four components are outlined: (1) Presentation of problem by presenting a medical history of symptom discovery; (2) Presentation of symptoms in a list using medical terms, extreme case formulations (Pomerantz 1986), and elliptic constructions; (3) Presentation of a candidate medical cause supported by referring to evidence and sources; and (4) Presentation of objective facts and other sources as the expected solution in terms of finding a cause.

The first response is also analyzed in detail. As an example of typical ways of responding to a problem presentation in the forum, I outline practices of claiming and showing identification by telling about personal experiences, making suggestions for action, and challenging health professionals' ways of treating the descriptions of experiences. The response is highly supportive in its form. I present an overview of the other eight responses in the posting in terms of the main activities achieved in them, which overall confirms the pattern and further contributes to the legitimization and validation of the experiences by indicating stories, assessments and advice. It is argued that these postings contribute to the objectification of experiences by delivering perspectives that can be used as information sources and for experiencebased generalization.

The paper illuminates two related methodological and theoretical issues: 1) it shows how participants interactionally and collaboratively arrive at a common understanding of how to understand a subjectively experienced problem available to them in an online forum by illuminating how problems are presented and accounted for by constructing subjectively experienced pain and bodily disturbances as medically recognizable phenomena and by seeking social validation of this knowledge and experience from forum members, and 2) it outlines ordinary people's lay understandings of experienced health problems. The "biomedical model of illness" (Wade/Halligan 2004) is overwhelmingly oriented to in the language used in an attempt to make sense of bodily experiences, i.e. participants "objectify" pain (Jackson 1994). The analysis shows that when medical knowledge gained from biomedical studies cannot be used to establish a medical cause, participants in the forum may objectify bodily experiences between themselves, namely by sharing experiences and thereby establishing subjective experiences as objectively recognizable in interaction. While not accomplishing to type themselves healthy, the paper argues that participants establish a common understanding that their problems are medically diagnosable and treatable (Gill 2005; Gill/Maynard 2006) and that they are not personally responsible for experiencing them. 


\section{Research on objective and subjective perspectives on illness}

Qualitative studies using different methods such as interviews and observation have focused on health professionals' as well as patients' perspectives on illness with a focus on the subjective vs. objective division which is inherent in the modern Western medical model of illness, viewing the body in terms of biological factors (Yuill/Crinston/Duncan 2010). In a sociolinguistic analysis of how the indications of the medical concern are discursively explored in physician-patient talk, Hamilton (2004: 62) takes her point of departure in the traditional distinction made in medicine between symptoms and signs, "with symptoms being defined as 'subjective evidence of disease' and signs as 'objective evidence of disease"'. Hamilton (2004) remarks that it is tempting to associate symptoms with patients and signs with physicians. However, signs as observable phenomena may also be accessible to patients. Further, she points to the fact that there is a complex interrelationship between subjective symptoms and objective signs, both in the sense that the experience of well-being and objective signs do not always support each other, and in the sense that subjective symptoms such as emotional stress may influence objective signs such as pulse and blood pressure. Further, patients have access to their bodily experiences permanently, which provides them access to subtle physical changes which may not be available as objective signs to the physician.

Jackson (1994) investigates pain from a perspective of embodiment. According to Jackson (1994: 201) citing Csordas (1990), an embodiment perspective "requires that the body as a methodological figure must itself be nondualistic, i. e. not distinct from or in interaction with an opposed principle of mind". Jackson (1994) suggests that pain, regardless of origin and cause, is experienced by individuals in their bodies and that for example a distinction between physical pain and emotional pain is difficult. Further, from the sufferer's point of view, pain can be seen as preobjective, i. e. without a subject-object distinction. Such a distinction can then be created, for example by increasing objectification or subjectification (Jackson 1994: 223). Jackson in fact shows in an ethnographic research project in an inpatient chronic pain treatment center in New England that patients with chronic pain use language to objectify pain. This is understood by Jackson (1994: 209) as a sense-making practice: "It is when we try to pay attention to pain or to talk about it, to 'make sense' of it, that we objectify it". Hence, according to Jackson, people use the subject-object distinction in order to explain pain and find causes for pain rather than the distinction being a reflection of how pain is experienced.

As this research shows, doctors and patients have different knowledge, expertise, experiences and perspectives when it comes to medical illness, and they may use subjective and objective perspectives discursively in order to make sense of experiences in social interaction. In some cases, patients describe experiences of feeling rejected, ignored or belittled, for example in interviews (Werner/Malterud 2003) as well as in interactions with peers (Andersen in press). People who experience a physical problem may seek other sources of information than what is available in traditional health care, e. g. they may seek online information and interaction in online media. In this paper, I focus on how an open online forum is used to indicate, share, negotiate and validate understandings of experienced health problems between members of the forum. 
Online forum interaction of health topics between peers forms a significant source of knowledge about aspects of ordinary people's (and often patients') sense making practices regarding both subjective experiences related to their problem, their "lay diagnosis" practices and to other phases of the problem trajectory than the medical encounter itself, which has been the focus of most interactional research about health (Beach 2001; Heritage/Maynard 2006; ten Have 2001).

\section{Online health interaction between peers}

A growing body of research focuses on the linguistic and discursive practices found in online health interaction, among other things interaction between lay people. Stommel (2009) coined the term "forumable" to refer to the normative practices new forum members orient to when they present their problem. In the online forum on eating disorders investigated, empirical investigations showed that "forumability encompasses being not too severely depressed and being knowledgeable of the various medical/diagnostic terms" (Stommel 2009: 160). Armstrong/Koteyko/Powell (2011) focused on how the identity of a UK-based diabetes Virtual Clinic online community was established by following it for six months after its inception. They show how participants draw boundaries between what is acceptable and what is not, and that participants work to present themselves as reliable and as authoritative sources of information. These studies point to the fact that although forum participants have not turned to health professionals, and hence may not consider themselves or other participants entitled to make diagnostic claims (Stommel 2009), they are highly concerned with how they present themselves and their problems.

As I will show and unfold below, one format for presenting a problem is a narrative. Thurnherr/Rudolf von Rohr/Locher (2016) show by comparing three online health practices focused on advice giving that narrative passages may have many different functions as part of participants' practices of constructing identity and doing relational work depending on medium factors and interactional goals of the practices. Hamilton (1998) investigated an electronic discussion list on bone marrow transplantation. She focused specifically on linguistic practices of using reported speech as part of medical conflict narratives, i. e. previous encounters between participants and medical professionals. Hamilton (1998) argues that the use of reported speech contributes significantly to socialize readers of the posting into a survivor identity as opposed to a victim identity.

It has also been documented that online health interaction between lay people often involves responses or feedback, often in the form of advice. Much of this research has focused on politeness and has demonstrated participants' strategies to provide advice indirectly and in mitigated form. Harrison/Barlow (2009: 106) refer to the advice practice that they find in an online arthritis workshop as "shared". In the workshop, all participants are expected to both give and receive feedback, and when they give feedback in the form of advice they tend to demonstrate experience of the recipient's problem, thereby constructing themselves as expert patients rather than for example health professionals. Kouper (2010) investigated the pragmatics of peer advice interactions in an online community at LiveJournal.com on motherhood. In line with the findings of Harrison/Barlow (2009), Kouper's analysis showed that both the soliciting and giving of advice include personal stories that perform a variety of functions be- 
sides requesting for and providing information and directions for future action. Morrow's (2006) study of an Internet discussion forum about depression adds to this by focusing on the language of problem messages, advice messages and thanks messages. Among the features he found were expressions of feelings in problem messages, expressions of solidarity and positive regard in advice messages, and a lack of evidence that anyone followed any of the advice that was requested or offered.

\section{$4 \quad$ Analytical method}

In this paper, conversation analysis (CA) is explored as a method to investigate online interaction in the form of forum postings. Increasingly, researchers apply CA on various types of online data (Giles et al. 2015; Meredith/Potter 2014; Stommel/Koole 2010).

CA has traditionally been occupied with questions about how ordinary people achieve a common understanding interactionally and locally by mainly focusing on instances in which talk has been used as a primary resource to achieve this (Hutchby/Woffitt 2008; Sidnell/Stivers 2012). Through micro-analysis of recorded naturally occurring interactions, CA studies have pointed at how a common understanding is achieved by participants in interaction sequentially in turn-at-talk in which each contribution to interaction is produced and made sense of (Sacks/Schegloff/Jefferson 1974; Sidnell/Stivers 2012). When talk is used as a resource, participants can usually monitor the production of speech, such that they can process the talk and respond during and immediately after its production (Levinson 2012). Thus, timing is essential for the production and sequential coordination of talk. This is different when writing is used as a main resource, since participants usually cannot monitor the presence of other participants and the production of interactional contributions. However, timing may still be a participant's concern (Meredith/Potter 2014). As argued by Giles et al. (2015), the basic CA concern with how participants achieve a common understanding in interaction should focus on the specific resources available and orientations of participants involved in online interactions by using various online platforms.

Smithson et al. (2011), for example, use CA methodology to investigate troubles telling and responses to those in an online forum for young people who self-harm. They show that there is a tendency in the forum to respond to troubles tellings with advice rather than for example empathy. Researchers who share methodological principles with CA focusing on participants' perspectives using naturally occurring online data and viewing language as action (Lamerichs/te Molder 2003) have among other things focused on how coherence is constructed and created interactionally (Reed 2001). Some of this research has also drawn from related methodologies such as discursive psychology (Sneijder/te Molder 2004, 2005), an approach focusing on how psychological issues are managed and used in social interaction (Edwards/Potter 2005), and membership categorization analysis that focuses on the interactional use of categories of person (Schegloff 2007b; Stommel/Koole 2010), thus shifting the focus to identity construction and accountability. 


\section{$5 \quad$ Data}

In order to provide detailed, sequential analysis, data consist of one thread including in total ten postings from an online discussion forum on the topic metabolism on the Danish health website netdoktor. $d k$. The thread is chosen because it entails a variety of accounting practices found to reoccur in the forum when participants experience undiagnosed illness. The forum is open, allowing everyone who navigates to the forum to read postings. However, formal membership must be obtained by signing up in order to initiate threads and respond to postings. Participants who initiate threads are invited to formulate a title for their posting, and threads develop when participants post responses to a posting. Netdoktor Media A/S has given permission to use the data for analysis given that participants usernames are anonymized. The usernames have therefore been changed such that the first participant in the thread is referred to as WR1, the second participant as WR2, etc. (see Myrendal 2015 for a review of ethical considerations concerning data collections of online material). In total eight participants contribute in the thread, WR2 and WR6 contribute twice, but the thread initiator, WR1 does not post any response to the responses she gets, for example in some form of a thanks-message (Andersen 2015; Morrow 2006). As the data are originally written in Danish, an English translation will be provided.

\section{$6 \quad$ Analysis}

As mentioned, the data consist of ten postings in a thread. The thread has been given the title Jeg tror jeg har for lavt stofskifte 'I think I have too low metabolism' by the writer of the first posting. Both the individual postings as well as the organization between the postings are complex in terms of the actions being performed. Therefore, this section is initiated with a detailed analysis of the first posting, focusing on how a problem is presented and how responses are invited. More specifically, the analysis points at practices used to objectify the problem described. As an example of how the problem is responded to, the first response is analyzed in detail, specifying how the practices used by the respondent acknowledge this understanding of the problem and work to validate the objectification interactionally and, hence, socially. Finally, a structural overview of the posting in the thread is presented and used to discuss the interactional and social achievements of forum interactions concerning topics related to persistance of experiences with pain and bodily disturbances despite having sought medical assistance.

\subsection{Objectifying subjective experiences through narrative-like components}

I analyze the first posting in terms of four components with narrative-like features. The analysis will unfold how each component entails practices working to present and socially make sense of experiences, both by objectifying experiences, by accounting for challenging health professionals, and by claiming a medical cause for undiagnosed illness: (1) Problem presentation as medical history; (2) Symptom presentation: Subjective symptoms and objective signs; (3) Suggesting candidate diagnosis by using warranting strategies; and (4) Facts and sources as solutions. Before moving on to the analysis of the four mentioned components, the very beginning of the posting will be analyzed in terms of how WR1 initiates her posting and addresses a specific group of recipients to which her actions can be held accountable. 


\section{Setting the frame of accountability}

Patients, or lay people who experience a physical problem which may lead them to seek medical care, have different knowledge, expertise, and experiences available than medical professionals do. In the following, I focus on the language used to present such a problem, not in the presence of medical professionals, but in an online forum for ordinary people. The entire first posting will be presented chronologically. However, for analysis, the posting is divided into excerpts.

The recipients are addressed and categorized in the posting itself (see example (1)). WR1 greets the recipients and addresses them as alle sammen, der gider at lase med 'all of you who bother to read along'. She also indicates that she views en garvet kvinde eller mand med forstand på denne sygdom 'an experienced woman or man who knows about this illness' as the ideal recipient and potential respondent.

(1) Kare alle sammen, der gider at laese med. Jeg håber at der sidder en garvet kvinde eller mand med forstand på denne sygdom. (WR1, first posting, very beginning)

'Dear all of you who bother to read along. I hope an experienced woman or man who knows about this illness sits out there.'

This opening accomplishes various interactional work such as initiating the first step in what may become an online interaction between several participants. Further, it establishes a frame of understanding for the interaction, namely that the writer has designed her posting for specific co-participants, namely participants who are addressed, described and categorized (Schegloff 2007a). She also alludes to the purpose of the posting, namely getting at least one response from one of them. By doing so she makes herself and her actions socially accountable to this specific group. In this opening, WR1 distinguishes between recipients and respondents, i. e. she is assuming that there is a group of people who reads the postings, but that she could not expect everyone who reads to respond. Hence, here there is an orientation towards the fact that unknown and yet unidentified recipients are addressed. This is achieved by the use of descriptions and categories using known or preferred characteristics and attributes of online forum readers/posters.

\section{Problem presentation as medical history}

WR1 continues to identify herself and to present her problem in a complex narrative (see below). The organization of this telling is different than narratives constructed in talk as recipients in face to face interaction ordinarily align as story recipients in the course of a telling and thereby co-construct the telling (Hutchby/Woofitt 2008). This is not possible here since the interaction is asynchronous (Herring 2007) in the sense that recipients cannot observe the production of a posting, but only have access to the complete posting which has been posted as a unit (Andersen 2015). In fact, many of the actions accomplished in the postings have features recognizable from narratives; however they are not full blown narratives in the Labovian (1972) sense, i. e. they may not be formatted as a classic narration with a reporting of past events, complication, climax, and evaluation (see Georgakopoulou 2007; Labov 1972). Instead, they may be characterized as tellings or "small stories" as described by Georgakopoulou (2007). In this framework, the focus is less on formal requirements and more on partici- 
pants' perspectives and practices: "what narrative does in specific sites; what the local theories about it are"; "what does treating a format of telling as a story mean for the prior or upcoming talk?" (Georgakoupoulou 2007: 39). Instead of formal criteria, Georgakopoulou (2007) characterizes narratives found in both conversational stories of adolescents and email exchanges as social actions. She states the following:

Narratives are of utmost importance in both these communication contexts as ways of jointly interweaving events and characters from daily experience and (re)fashioning interpretations of them. They are also fundamental acts of sharing and through doing so, reaffirming closeness in positions and viewpoints, putting them to the test, or revisiting them.

(Georgakopoulou 2007: 40)

The construction of the posting, including the narrative-like elements and the categories used to describe WR1's problem, indicate her understanding of how a telling about a physical problem can be relevantly and legitimately delivered in the forum addressed at potential fellow sufferers.

The telling, which may be categorized as a problem presentation (Heritage/Robinson 2006), entails four components which are found to be characteristic of problem presentations in the forum (Andersen 2015): Presenting the problem as a medical history, presenting the problem by referring to both subjective symptoms and objective signs, addressing diagnosis and treatment options, and addressing appropriate ways of acting on the problem, including inviting forum participants to respond. As mentioned above, participants may indicate various sorts of problems. However, this posting and the responses to it were chosen for analysis because they represent a pattern in terms of the construction of and interactional treatment of a problem and in terms of sequential organization. More specifically, it represents a pattern of objectifying subjective experiences, of accounting for countering medical professionals, and of indicating objective facts in combinations with small stories to achieve these ends interactionally.

WR1's posting is built as a narrative about WR1 and is announced by WR1 as such (Kan fortcelle kort om mig selv 'I can briefly tell about myself'). The beginning of this narrative is constructed as a chronological medical history starting ten years back with the birth of WR1's son:

(2) Kan fortcelle kort om mig selv. Jeg er kvinde og 42 år. For ca. 10 år siden fødte jeg min søn, som jeg fik ved hjalp af Ivf. ${ }^{3}$ Lykkelige var vi jo at det lykkedes. Men der gik ikke så lang tid, før jeg blev trist. Jeg har så igennem de sidste 10 år varet on and off $i$ behandling for depression, uden hensyntagen til alle mine andre symptomer. Idag har jeg mistet mit job er på kontanthjalp og livet ser generelt temmelig sort ud. (WR1, first posting)

'I can briefly tell about myself. I am a woman and am 42 years old. About 10 years ago, I gave birth to a son whom I had by the help of IVF. We were of course happy that it succeeded. But it wasn't long before I became sad. I have then during the last 10 years been on and off in treatment for depression, without consideration about all my other symptoms. Today I have lost my job and am on social assistance and life generally looks dark.'

\footnotetext{
${ }^{3}$ IVF is a type of fertility treatment called 'In Vitro Fertilization'.
} 
People talking about a potential health problem have been observed to produce narratives of problem discovery. Halkowski (2006) describes how such narratives are accomplished in doctor-patient interactions, and how they are used to display "doctor-relevance", i. e. how the patients can show themselves to be "reasonable patients" and hence socially accountable in that social setting. These narratives often have a specific structure as they first announce the problem, then indicate an initial hypothesis for the cause of the pain, and finally describe events that point in another direction (Halkowski 2006: 87). The narrative constructed by WR1 includes similar elements. WR1 announces (in the title) and elaborates on an experienced problem (see how the posting unfolds below). However, WR1 not only suggests a hypothesis for a cause for the pain herself, she actually complains about the doctor's initial hypothesis (i.e. depression), which has led to diagnosis and treatment, and she then describes indications pointing in another direction (i.e. symptoms that persist despite treatment). Hence, WR1 is now accountable for countering a health professional's diagnosis and treatment of her. This accountability is oriented to in the construction of the narrative, in which WR1 shows that she has acted appropriately and reasonably before addressing the forum by acting according to medical treatment recommendations and by orienting to facts.

Building on Jefferson's (1988) analysis of practices people use to avoid trouble in ordinary interaction, Heritage/Robinson (2006) list two ways patients circumvent trouble in doctorpatient interaction: patients tend to show they have attempted to cope with the problem prior to seeking medical assistance, and they tend to show that they are currently coping with their problem with fortitude. For example, they mention that this is done by presenting objective facts only. Similar orientations can be found in WR1's narrative, which is presented in the form of a medical history including facts about symptoms, diagnostic claims and treatment. In her work to reject the doctor's diagnostic claim, she presents her arguments as facts based on previous events and causal relationships (or lack of such) documented by her experiences of persistence of symptoms despite medical treatment.

\section{Symptom presentation: Subjective symptoms and objective signs}

WR1 presents her current problem as an increase of symptoms during the last three years. WR1 thereby, again, makes use of medical categories to describe her problem, i. e. she presents her problem as a medical, and objective, problem. She also makes use of a method to indicate her symptoms, namely a list construction, which may draw on medical discourse similar to the language known from medical descriptions of illnesses, for example found in information leaflets about drugs. Moreover, this list construction packages each symptom as part of a whole, thus projecting the symptoms to belong together, and possibly to be explained by a single cause. Not only the words, but also the layout of this part of the posting, are used to construct experienced problems as a list of medical symptoms:

(3) De sidste 3 år er symptomer udover depression kommet slag i slag

- Jeg er ekstremt trat,

hukommelsen er nasten ikke eksisterende,

jeg fryser meget

Jeg har ledsmerter

Mine yderste фjenbryn hår er vak

ISSN 1615-3014 
Jeg kan ikke tabe mig

Havelser i hovedet, store render og poser under фjnene

Initiativlфs

Har ikke lyst til at vare sammen med mennesker

Men det varste er dog mit hovede, det er simpelthen ikke sig selv, har last flere steder omkring det og det kaldes forskelligt bl. A. Brainfog, hvilket jeg syntes passer rigtig godt.

Det er snart toet på at jeg giver op. Jeg er celdet 10 år i lфbet af ingen tid. (WR1, first posting)

'The last 3 years, symptoms besides depression have come blow upon blow

- I am extremely tired,

The memory is almost non-existent.

I am cold a lot

I have joint pains

My outer eyebrows are gone

I can't lose weight

Swollen in the head, big circles and bags under the eyes

Without initiative

Don't feel like being with other people

But the worst, however, is my head, it is simply not itself, have read several places about it and it is called different thing, among other things Brainfog which I think fits really well.

It is almost close to the point where I give up. I have aged 10 years in no time.'

WR1 indicates that the symptoms she lists can be seen as symptoms not related to depression, the psychological disorder she is diagnosed with (symptoms besides depression). The list consists of ten items. Using the traditional distinction between subjective symptoms and objective signs as used by Hamilton (2004), we can notice that WR1 both indicates subjectively perceived indications of a medical problem such as extreme fatigue, being cold, and experiencing joint pains as well as objectively observable signs such as a swollen head, dark circles and bags under the eyes, and the outer part of the eyebrow missing. Indicating both subjective and objective evidence of disease of course strengthens the case made that WR 1 is in fact experiencing something which requires further medical attention.

The descriptions of experiences and signs of illness are constructed with various linguistic formulations that work to legitimize the claim made that the descriptions should be understood as symptoms of illness not previously identified by a doctor. These formulations include the use of adverbs that qualify the descriptions of experiences such as ekstremt 'extremely' and meget 'a lot', the use of the formulation det varste 'the worst', and the use of the modal verb kan 'can' connected with a negation which is used to indicate that some state of affairs (losing weight) is not possible. Formulations of this sort have been referred to as "extreme case formulations" and have been described to work to "propose a phenomenon is "in the object' or objective rather than a product of the interaction or the circumstances" (Pomerantz 1986: 220) among other things. Hence, by using these extreme case formulations which are specifically used in descriptions of subjective experiences, WR1 constructs these descriptions 
as experiences out of the ordinary, as recurrent and not related to specific circumstances in everyday life that may explain their occurrence as ordinary and unproblematic experiences.

WR1 indicates her experiences as objective and related to medical illness by other means as well. She uses constructions with the verbs vare 'be' and have 'have' to attribute an experience to herself such as - Jeg er ekstremt traet '- I am extremely tired'; Jeg har ledsmerter 'I have joint pains'. As they are presented as items of a list of symptoms that have occurred increasingly within the last three years, the experiences are understood as not necessarily occurring in the present moment of writing, but as having occurred regularly and recurrently. In some of the latter descriptions in the list, the subject, jeg 'I', is left out (in some cases also a verb), leading to elliptic constructions (Rathje 2013), for example Havelser $i$ hovedet 'Swollen in the head'; store render og poser under ojnene 'big circles and bags under the eyes'; Initiativlфs 'Without initiative'; Har ikke lyst til at vare sammen med mennesker 'Don't feel like being with other people'. This, along with the use of parts of the body or the mind as subject of a sentence, may further be seen as linguistic means used to objectify experiences and signs. Finally, she constructs a part of her body, the head, as an individual entity and agent which is not itself anymore, and she connects the description with a commonly used term Brainfog, which she came across in her search for information.

\section{Suggesting candidate diagnosis by using warranting strategies}

Following example (3) and towards the end of the posting, WR1 addresses the issue of medical examination and treatment, somewhat parallel to traditional medical approaches in which these phases would typically follow a problem description (Heritage/Maynard 2006). She does that by constructing a telling which takes its point of departure in the experiences of a third party, WR1's mother, during the last three months.

(4) Skabnen ville så at min mor for ca. 3 mdr. Siden fik diagnosen lavt stofskifte, hun købte Helle Sydendals, bog få livet tilbage hun ringer mig op fuldstandig chokeret og siger hun ved hvad jeg fejler. Hehe. Ja det ville jo vare vidunderligt :-) (WR1, first posting)

'Fate wanted that my mother got the diagnosis low metabolism about 3 months ago, she bought Helle Sydendal's book get life back she calls me in total shock and says she knows what is wrong with me. Hehe. Yes that would be wonderful :-)'

In this telling, it is a third party who discovers that symptoms of the diagnosis lavt stofskifte 'low metabolism', which she was diagnosed with herself, match the symptoms described by WR1 to an extent that she is reported to have said that she knows what is wrong with WR1. Hence, in this telling a candidate medical cause for WR1's problems is suggested. The source of information which led the mother to the discovery is also named, namely a book. Invoking third parties has been described as a practice patients use in doctor-patient interaction as part of their strategies for legitimizing their visit to the doctor, i. e. to present their problem as "doctorable" (Heritage/Robinson 2006: 71). As the authors mention, the invocation of third parties may have the function of presenting "their conclusions as already shared and, to this extent, validated or 'sanctioned' (Zola 1964, 1973) by another person" (Heritage/Robinson 2006: 71). WR1 both invokes a non-professional, her mother, as well as a source of professional information in the form of a book. Using these third-party sources may work to maximize the effect of her claim (Heritage/Robinson 2006). Richardson (2003) investigating a cor- 
pus of about 1000 messages about the health risks of mobile phone handsets in Usenet newsgroups, pointed out how participants used a variety of warranting strategies when presenting and discussing health risks. Those strategies included referring to sources, drawing upon personal experience, using a personal contact as an expert, using self as an expert, and using a technical register. According to Richardson (2003), the function of such warranting strategies is to establish the sources of authority of claims. As WR1 is countering a medical professional's assessments with her suggestion, her actions are accountable. Hence, these warranting strategies may be seen as practices orienting to this accountability.

WR1 indicates her reaction to the suggestion made by the mother by writing laughter tokens (hehe), by indicating an acknowledgement token ( $\mathrm{ja}$ 'Yes'), by assessing it as wonderful wishful thinking (Det ville jo vare vidunderligt 'that would be wonderful'), and by adding a smiley (:-)). Thereby she accomplishes showing that she is hopeful in regard to finding a medical diagnosis that could account for her symptoms and make new treatment options relevant.

Now, WR1 is accountable for how she acts after having been provided with possibly relevant new information from third parties. This is oriented to in the following excerpt in which WR1 indicates that she acted immediately and presented the doctor with the information.

(5) jeg tager jo straks til min lage og fortaller hende om min nye opdagelse. Hun siger at vi jo javnt over årene har taget den blodprøve, da jeg også er lidt overvagtig og at mit stofskifte er normalt. Havde jo så "opskriften" med fra bogen omkring hvilke prøver der skal tages og beder hende om nogle nye prøver. Dem indvilger hun i at tage. (WR1, first posting)

'I go to the doctor immediately and tell her about my new discovery. She says that we have regularly taken that blood test since I am also a bit overweight and that my metabolism is normal. I had the "recipe" along from the book about what tests should be taken and ask her for some new tests. She agrees on taking them.'

The data, thus, present accounts of medical visits, rather than accounts for the visit seen in doctor-patient encounters (Heritage/Robinson 2006). WR1 reports on how she acted on the new information and on how the doctor responded to the news, namely by rejecting low metabolism as a relevant cause based on previously used medical objective measures, blood tests, which WR1 is reported to have responded to by requesting a medical evaluation based on specific new tests. These practices of reporting on what was said in a previous medical encounter resonate with Hamilton's (1998) findings about the use of reported speech in online narratives about bone marrow transplantation. She found that participants report on the doctor's utterances directly much more often than on the utterances of the patients themselves. Further, she found that patients are presented as using the same proportion of initiating actions as the doctors do, and that patients are being more assertive in interactions with doctors than research on actual medical encounters documents. In example (5), WR1 constructs the narrative as based on her initiatives of going (tager 'go'), and asking (beder 'ask') and the doctor as the one responding by saying (siger 'says') and agreeing (indvilger 'agrees'). Most of this reporting of past events is formulated in the present tense (tager 'go'; siger 'says'; beder 'ask'; indvilger 'agrees'), which may work to stress the immediacy of her reaction to the new information presented to her (example (4)) and to involve co-participants.

ISSN 1615-3014 
The results of the tests are also reported in the posting:

(6) Men $\phi v$, fik svar i dag, de var vist ok, kun en smule for højt anti et eller andet, som vi skulle holde фje med og ikke ville behandle på. (WR1, first posting)

'But, aw, got the response today, they appeared to be okay, only a little too high anti something that we should keep an eye on and wouldn't treat.'

WR1 both indicates her assessment of the results of the tests and the doctor's assessment and recommendations on the basis of them. The tests are assessed as only slightly deviant and only requiring observation, no treatment. While such an assessment might lead to relief for some patients, WR1 indicates disappointment (aw).

\section{Facts and sources as solutions}

WR1 elaborates on the disappointment, showing how she had been convinced that the medical disorder low metabolism would be established as the cause for her experienced problems.

(7) Åhhhh, sikke en nedtur, var sikker på det var stofskiftet er faktisk stadig sikker på at det er stofskiftet. Men hvad går jeg hjem med, en ny henvisning til psykiater og endnu en recept på lykkepiller. Hjalp, hvad gфr jeg nu. (WR1, first posting)

'Ahhhh, what a downer, I was sure it was the metabolism am actually still sure that it is the metabolism. But what do I go home with, a new reference to a psychiatrist and another prescription for antidepressants. Help, what do I do now.'

Instead of being diagnosed with and treated for low metabolism, WR1 reports she is treated for the mental disorder depression as previously. As a response to this, she seeks help and formulates a question (hjoelp, hvad gфr jeg nu 'Help, what do I do now'). It might be noted that the question is not finished with a question mark, which may or may not be intended. Hence, this response may not only be understood as a way for WR 1 to indicate her reaction to the treatment (i. e. feeling helpless), it may also be a strategy to invite forum participants to respond with suggestions for how WR1 can remedy her situation (see Rudolf von Rohr 2017 for an example of a more indirect practice for seeking support in online smoking cessation).

Stommel (2009) shows, in a study of an online support group on eating disorders, that people who seek help are accountable by providing good reasons for doing so. Further, Stommel (2009) found that forum participants tend not to ask for help directly and tend to show that they don't rely completely on the service of the forum. In example (7), there is an action which is understandable as a direct request for help in the form of an imperative and a question; however, it is placed in the context of a telling about how authoritative sources were not able to provide the help sought by WR1. This strategy of asking for help in an imperative format may add to the sense of disappointment and discontent with the treatment by medical professionals and construct a sense of desperation on WR1's part, adding to the accountability of turning to the forum with a problem constructed as medical. In the continuation of the post WR1 shows that she does not give up. She restates the belief that she felt confident that the underlying cause for her problem was a metabolic disorder and provides forum participants with information about the medical tests that were used as a basis for rejecting lavt stofskifte 'low metabolism' as a cause for her problems. She uses the strategy of invoking third parties 
(Heritage/Robinson 2006) to indicate the suggestion that medical examinations and tests may not suffice as techniques to establish a medical diagnosis correctly:

(8) Var så sikker i min sag!

Mine tal - ikke fastened

Thyrotropin (TSH)P 2,2 gransevardi 0.20-5.0

Thyroidperoxidase - Ab P H626. $<60$

Thyroxin (T4)P 103.60-160

Triiodthyronin frit (T3) P 4,3.4.1-6.9

Jeg har snart laest så mange steder at på trods af 'fine' tal at den så godt kan vare helt gal. Og jeg føler virkelig at den er gal. (WR1, first posting)

'I was so sure of success!

My numbers - not fasting

Thyrotropin (TSH)P 2,2 limit value 0.20-5.0

Thyroidperoxidase - Ab P H626. $<60$

Thyroxin (T4)P 103. 60-160

Triiodthyronin free (T3) P 4,3 . 4.1-6.9

I have read in so many places that despite my 'good' numbers that something can be wrong.'

In the last part of example (8), WR1 refers to written information from different sources. By doing so, she shows that she understands a perspective that focuses on objective facts to be relevant. Although it is unclear what the sources might be, forum postings may be such a source. Hence, WR1 may refer to other patients' stories or other types of information.

WR1 adds to this description that she does have the feeling that something is wrong:

(9) Og jeg føler virkelig at den er gal. (WR1, first posting)

'And I really feel that it is wrong.'

With this description, WR1 makes a claim about her wellbeing, and she indicates that she makes it on the basis of her sensation or experience. She stresses, again, that her experiences are seen as a problem which cannot be accounted for by ordinary everyday sensations (Halkowski 2006) or a psychological disorder, which WR1 has indicated evidence for throughout her posting.

The resort WR1 turns to with her persistent experienced problem is an online forum on metabolism. She accounts for turning to the forum by (1) presenting a medical history in which the normative first resort, health professionals, have provided a service reported not to have addressed every symptom experienced by WR1; (2) providing evidence both in terms of objective signs and subjective experiences indicating the persistence of a medical problem despite treatment for a psychological disorder; and (3) presenting a hypothesis suggesting the problem to have an underlying medical cause, low metabolism, supported by various evidence and sources, however not supported and confirmed by medical professionals.

These efforts can be understood to address a central concern for WR1: Undiagnosed symptoms of illness, and hence unaccounted for persistent, recurrent and problematic physical, 
social and psychological experiences, despite having sought medical care. WR1 attempts to make these experiences socially accountable by objectifying them discursively. To do so, she turns to potential fellow sufferers on the online forum.

\subsection{Objectifying subjective experiences interactionally}

As argued for previously, members of society claim, negotiate, challenge and are faced with problems of social accountability in everyday social activities, i. e. in interactions with other members of society. Therefore, it is crucial to investigate how someone's social actions are responded to by co-participants (Hilbert 1984; Stommel 2009).

The posting scrutinized above was responded to with nine responses. A total of eight participants responded. Although WR1 initiated the thread, she does not contribute with any responses to the postings in which she or her problem is addressed (see Table 1 below). The first response will be analyzed in detail with the purpose of outlining interactional components contributing to the validation of the objectification of subjective experiences. The components include ways of claiming and showing identification by telling about personal experiences, by recognizing and managing problems, by sharing experiences through stories, and by challenging health professionals' ways of treating the descriptions of experiences.

In the final part of the analysis, the sequential organization of the thread more broadly will be given some attention. It is pointed at how the patterns outlined are systematic and recurrent, even within a single thread in the sense that participants who respond acknowledge the problem described in the first posting and contribute to the legitimization and validation of it by indicating stories, assessments and advice. It is argued that the social practices accomplished by the members of the forum are indicative of a social problem of accountability.

\section{Claiming identification}

The first response to the first posting in the thread investigated is posted by a participant referred to as WR2 about three hours after the first posting had been sent. It is initiated with a greeting, an agreement as well as a claim of identification:

(10) Hej. Du har sikkert ret. Jeg står i samme situation. (WR2, second posting)

'Hi. You are probably right. I am in the same situation.'

WR2 treats the first posting as making relevant some uptake in the form of an agreement, i. e. WR2 seems to treat WR1's posting as an argument for a specific view of her problems to either agree or disagree with. WR2 modifies the agreement with the disclaimer sikkert ('probably'), and she also identifies herself as someone in the same situation as WR1. This identification provides information about WR2's grounds for stating an agreement: that action is based on experiences understood to be similar to WR1's to such an extent that WR2 categorizes them as the same. Having similar experiences is, as Sacks (1992b) describes, a powerful discovery of extended experiences, entitlement, and possibilities of generalization:

There are ways, then, whereby the isolating character of experiences can nonetheless get undercut - if what one is dealing with is that there are others who have the same experiences. Then, you have more extended experiences than you would have had if only you had had it, or you can see a pattern to experience, other than the one you would see if only you had had it. So, if we're 
talking about the ways in which the feelings that experiences generate can get amalgamated, then, on the one hand if you haven't had an experience you're not entitled to feel as they have, and on the other, if somebody tells you an experience you're not entitled to feel as they have, but on the third hand, if you've had an experience and you're told a similar experience by another, then you can make very big generalizations from it and feel more than you would have felt in either of the prior two cases.

(Sacks 1992b: 246)

Identification used to identify with someone else's experiences in this context works to provide entitlements to doing actions such as providing agreements, etc. Eichhorn (2008) in fact showed that invitations to share experiences was the most frequent soliciting strategy for social support in an online eating disorder support group. Further, the accomplishment of establishing identification between participants in the forum provides them with a resource to generalize and hence objectify their subjective experiences which they have not been able to get validated medically through a medical diagnosis.

\section{Objectifying subjective experiences using second stories}

Identification is not only claimed, as in the excerpt above. It is also demonstrated. WR2 describes her personal experiences and relates them to the actions provided by WR1, in what can be called a second story (Arminen 2004; Sacks 1992a). According to Arminen, second stories are a particular type of response to an original story found in conversation. What is achieved by a second story is that "the teller not only claims but proves his understanding of the first story through the designed resemblance of the second" (Arminen 2004: 321).

(11) Har varet plaget i 4-5 år, men har det usigeligt varmt. Sveden lober af mig og jeg får feber ved aktivitet. Er som du hovet omkring фjnene, bliver tykkere og tykkere, er trat, trist, uoplagt, irritabel m.m. Mit TSH er 5.24. Øvrige tal har jeg ikke. (WR2, second posting)

'Have been plagued for 4-5 years, but feel inexpressively hot. The sweat runs off me and I have a fever when active. I am as you swollen around the eyes, become thicker and thicker, am tired, sad, lethargic, irritable etc. My TSH is 5.24. Other numbers I don't have.'

In her second story, WR2 makes a truncated medical history, describes a list of symptoms, some of which are indicated to be similar to WR1's (som $d u$ 'as you'), and she indicates the blood test result of a medical examination, thereby also indicating that she has consulted a medical professional. By providing specific symptoms following upon WR1's list of symptoms, the second story makes specific generalizations of experiences possible. Since only patients and not doctors have access to the experiential side of illness, forum participants can share and generalize on experiences which health professionals do not have entitlement and access to (see quote from Sacks 1992b above). 


\section{The problem of social accountability as a shared problem recognized and managed through stories}

Having indicated shared experiences with WR1, WR2 problematizes the general lack of social validation she has experienced:

(12) Det er aldeles radselsfuldt, og ekstrem hårdt, da der ikke er mange der forstår hvordan man har det. Foler mig som en hypokonder. (WR2, second posting)

'It is absolutely horrible, and extremely tough, since not many understand how one feels. I feel like a hypochondriac.'

Thus, when it comes to the experience of bodily pain and disturbances, social accountability is indicated as a central aspect of these participants' concerns and described as an integral part of illness experiences. The lack of social accountability, i. e. lack of understanding and social identification and validation, makes the illness extremely tough, according to WR2.

Arminen (2004) who investigated the therapeutic uses of stories in the form of personal monologues following upon each other at Alcoholics Anonymous (AA) meetings, shows how second stories may be a means not only to reveal personal problems reciprocally, but also to revisit and reevaluate the problems. WR2 continues her posting with a telling about her medical evaluation process that finally lead to a decision to change doctors.

(13) Jeg er unders $\phi g t$ for narmest alt - undtagen lige det - det er i hvert fald ikke taget spor seriфst. Har lige skiftet lage. Det er Dog med for høje tal ${ }^{[4]}$. (WR2, second posting)

'I have been examined for almost anything - except just that - that has surely not been taken seriously at all. I have just changed to another doctor. It is, though, with too high numbers.'

This small story is built to legitimize a delegitimization of WR2's now previous doctor, resulting in a change of doctor, and argued for by indicating that experienced symptoms were not taken seriously by him/her. While not constructed as advice, this story may, as Arminen (2004) suggests, work to reevaluate other participants' problems due to the story's recognizability to others, and hence may lead them to draw similar conclusions as WR2.

\section{Questioning and challenging professionals' medical diagnostic methods and categories}

WR2's previous doctor is accused of not taking WR2's symptoms seriously. This is elaborated on by WR2 who indicates that the initial diagnosis or diagnostic claim the doctor made, turned out to be proved wrong.

(14) Min tidligere lage hang alt op på at jeg havde astma-det er nu bevist at jeg IKKE har. Ved div. undersøgelser er meget skubbet over på, at det må vare astmabetinget.

Har lige købt en bog af Helle Sydendal der hedder Få livet tilbage - kan anbefales varmt.

Håber vi snart får bedring begge to. KH Xxxxxx (WR2, second posting)

\footnotetext{
${ }^{4}$ As described in the health website in which the discussion forum is found, metabolic disorders are often diagnosed by measuring the number of specific hormones and sometimes antibodies in the blood and comparing the results to normal values (Hegedüs s. a.). When WR1 refers to too high numbers, it may be understandable as an indication that previous blood test results have indicated hormone values above the normal range.
} 
'My former doctor attributed everything to the fact that I had asthma - I have proven now that I do NOT have. Concerning various examinations much has been pushed over to the cause that it must be asthma-related.

Have just bought a book by Helle Sydendal called Get life back - highly recommended. Hope we will soon be better both of us. Love Xxxxxx'

The doctor is described as someone who has overgeneralized and ascribed asthma to be the cause for every symptom described by WR2. As in the first posting, it is not the patient's first hunches that turned out to be wrong, but the doctor's. As WR1, WR2 also indicates how she responds to persistence in symptoms despite medical treatment. WR2 indicates to actively seek and use medical knowledge as she refers to the book also referred to by WR1, before she closes with expressions of positive regard.

Both WR1 and WR2 deal with the fact that they experience a persistence of pain and bodily disturbances despite having sought medical treatment. The analyses show that the participants are highly concerned with making their problems forumable (Stommel 2009), i. e. in this forum participants present their experiences as reasonable, persistent, recognizable, physical and embodied. In essence, the experiences are presented as medical symptoms with an objective reality. At the same time, the participants are highly concerned with rejecting their doctor's methods of objectifying their experiences, since these methods have not led to change. They do this, among other things, by telling stories documenting how doctor's initial diagnostic claims and treatment recommendations did not lead to the expected decrease of pain.

\subsection{Social accountability through stories}

As mentioned, the thread scrutinized consists of ten postings. An overview of the sequential organization in terms of who is addressed and the main activities accomplished in the posting can be found in Table 1. For each posting, a description of the main activity types occurring in them is provided along with an indication of writer and indicated recipient. The purpose of this is to be able to point to some interactional features of the entire thread, e. g. the recurrent use of narrative components to accomplish action initiating and responding to experiences of illness.

\begin{tabular}{|l|l|l|l|}
\hline $\begin{array}{l}\text { Posting } \\
\text { number }\end{array}$ & Participant & Response to & Main activity type \\
\hline 1 & WR1 & 1 (WR1) & WR presents a problem and invites help. \\
\hline 2 & WR2 & 1 (WR1) & $\begin{array}{l}\text { WR2 acknowledges WR1's problem and pro- } \\
\text { vides a second story. }\end{array}$ \\
\hline 3 & WR2 & $\begin{array}{l}\text { WRejpands the previous posting. Here she } \\
\text { cal disorder". }\end{array}$ \\
\hline 4 & WR3 & 1 (WR1) & $\begin{array}{l}\text { WR3 provides medical knowledge supporting the } \\
\text { claim that a metabolic disorder can be the cause } \\
\text { for problems despite blood test results within the } \\
\text { normal range. }\end{array}$ \\
\hline 5 & WR4 & 1 (WR1) & $\begin{array}{l}\text { WR4 suggests (WR1) to try a diet that has } \\
\text { worked for her. }\end{array}$ \\
\hline
\end{tabular}




\begin{tabular}{|l|l|l|l|}
\hline 6 & WR5 & $\begin{array}{l}\text { 1 (WR1) } \\
\text { And invita- } \\
\text { tion for other } \\
\text { members to } \\
\text { respond }\end{array}$ & $\begin{array}{l}\text { WR5 acknowledges (WR1's) problems, provides } \\
\text { a second - or "third" - story, and requests for } \\
\text { assessments. }\end{array}$ \\
\hline 7 & WR6 & 1 (WR1) & $\begin{array}{l}\text { WR6 provides assessments addressed at WR1 } \\
\text { including a medical diagnosis, advice on medical } \\
\text { examinations, recommendations regarding medi- } \\
\text { cal professionals, positive regard, and a second - } \\
\text { or "fourth" - story. }\end{array}$ \\
\hline 8 & WR6 & 6 (WR5) & $\begin{array}{l}\text { WR6 provides assessments addressed at WR5, } \\
\text { advice regarding diets, expressions of positive } \\
\text { regard, and recommendations for the use of a } \\
\text { forum to seek information. }\end{array}$ \\
\hline 9 & WR7 & 7 (WR6) & $\begin{array}{l}\text { WR7 invites WR6 to help her, she indicates a } \\
\text { problem regarding medical examinations, i. e. a } \\
\text { second - or "fifth" - story and invites help. }\end{array}$ \\
\hline 10 & WR8 & $?$ & $\begin{array}{l}\text { WR8 identifies as someone who has suffered } \\
\text { from a metabolic disorder for many years and } \\
\text { then provides a story about the discovery and } \\
\text { about how she had to struggle to get a medical } \\
\text { diagnosis and treatment, i. e. a second - or } \\
\text { "sixth" - story. }\end{array}$ \\
\hline
\end{tabular}

Table 1: Overview of thread structure and main activities

Several issues can be noticed from the overview. First, participants may acknowledge and support (and in some cases negotiate and challenge) the claims and understandings made about how experiences can be objectified in different ways. Many times practices in responses resemble the strategies already outlined in the previous analysis, e. g. they question and challenge health professionals' methods for objectifying symptoms (posting number 3 and 4), they describe previous actions performed with the purpose of dealing with the problems (posting number 5, 7 and 8), and they provide second stories including claims of identification, medical histories, and symptoms (posting number 2, 6, 7, 9 and 10). Second, within a thread, participants responding may present problems themselves, not only as a second story, but also as a possibly different problem that requires individual assessments and treatments (posting 6 and 9). By doing so, participants orient to an understanding that every person and hence every problem is complex and should be treated as such by including both medical, historical, mental, and social facts that may contribute to a fuller understanding of it. Moreover, participants orient to an understanding that social accountability is accomplished in interaction. By reaching out themselves, they acknowledge the interactional work accomplished by other participants who either present problems or respond with acknowledgements, knowledge, stories and/or advice. 


\section{$7 \quad$ Concluding remarks}

Many interactional studies of health care investigate the medical encounter itself, for example showing how patients present themselves and their problems as reasonable. This paper has attempted to outline some of the ways lay people who experience pain and bodily disturbances despite having sought medical treatment deal with that outside of the doctor's office, namely in an online forum in interactions with peers. The study focuses on how participants deal with and try to regain social recognizability, accountability and possibly even medical "diagnosticability" after failed medical encounters and treatments. The analysis shows that participants attempt to regain social accountability by presenting their problems in ways that objectify their subjective experience of illness, and by presenting health professionals' methods for assessing and treating their problems as flawed and not medically objective. Since the normative way to deal with persistent pain and disturbances in western societies is to consult medical professionals who are expected to use what is conceived as objective medical methods to diagnose and treat us, challenging the methods of health professions can be assumed to be a highly accountable activity. Details of the organization of the postings show that participants (see example (5) written by WR1 and example (13) written by WR2) orient to this by showing that they have sought medical advice themselves, that they have been reasonable, compliant, patient patients, but that their experiences with medical treatment prove the diagnostic claims and treatment recommendations to be flawed and not objective. Participants support each other in these attempts to have their perspectives acknowledged and validated by providing responses that entail acknowledgements (e. g. Du har sikkert ret 'You are probably right', WR2, example (10)), claims of identifications in the sense of being in the same situation (e.g. Jeg står $i$ samme situation 'I am in the same situation', WR2, example (10)), demonstrations of identifications by the use of second stories, medical knowledge, indications of previous actions and advice. The responses, moreover, contribute with a social and interactional validation of the objectified experiences, thus, possibly providing participants with validation of their experiences, making claims of generalizability and social accountability an objective reality.

Participants explicitly indicate that their actions are constructed for an online context between participants with knowledge and experience within certain health conditions and symptoms. Although it is an online context in which participants in principle can be anonymous by using usernames to identify themselves, they do identify themselves as certain types of people in and through the stories they tell about themselves. The accounting practices participants use in the forum point to the fact that participants are concerned with accountability when dealing with health issues. To a high extent, these accounting practices contribute to creating forum norms and a sense of "forumability" (Stommel 2009), i. e. they index participants' normative expectations of how people who experience undiagnosed illness symptoms should manage being in that situation.

In a Danish context, narrative medicine is slowly winning ground, both in research and in medical educational settings (Madsen 2017). Since some of the perspectives and experiences described by patients as troublesome are recurrently not being understood and recognized by health professionals (see also Andersen in press; Werner/Malterud 2003), this may lead to experiences by patients of not being treated as legitimate patients. Patients' stories in online 
forums may therefore be used as insights in initiatives in medical settings to embrace and understand patients' perspectives and experiences when faced with illness.

\section{References}

Andersen, Elisabeth Muth (in press): „Sygdom på nettet“. In: Køhler Mortensen, Kristine/Stæhr, Andreas (eds.): Sociale medier og sprog - digital sprogbrug og social praksis: En antologi om sprog og sociale medier på dansk. Samfundslitteratur.

Andersen, Elisabeth Muth (2015): What's your Problem?: On How Participants Understand and Deal with Experienced Bodily Problems in an Online Discussion Forum about Metabolism - A Contribution to Micro-Analytic Research that Investigate Online Data. Unpublished $\mathrm{PhD}$ thesis. University of Southern Denmark.

Antaki, Charles/Ardévol, Elisenda/Núñez, Francesc/Vayreda, Agnès (2005): “For she who knows who she is': Managing accountability in online forum messages". Journal of Computer-Mediated Communication 11/1: 114-132. doi: 10.1111/j.1083-6101.2006.tb00306.x.

Arminen, Ilkka (2004): "Second stories: The salience of interpersonal communication for mutual help in Alcoholics Anonymous". Journal of Pragmatics 36/2: 319-347. doi: 10.1016/j.pragma.2003.07.001.

Armstrong, Natalie/Koteyko, Nelya/Powell, John (2011): ““Oh dear, should I really be saying that on here?': Issues of identity and authority in online diabetes community". Health 16/4: 347-365. doi: 10.1177/1363459311425514.

Beach, Wayne A. (2001): "Introduction: Diagnosing 'lay diagnosis"”. Text 21/1: 13-18. doi: 10.1515/text.1.21.1-2.13.

Buttny, Richard (1993): Social Accountability in Communication. London: Sage.

Csordas, Thomas J. (1990): "Embodiment as a paradigm for anthropology". Ethos 18/1: 5-47. doi: 10.1525/eth.1990.18.1.02a00010.

Dansk online index (2016, September): "Dansk online Index Topliste". https://doi.kantarclarity.com/Storyboard/RHViewStoryBoard $\operatorname{aspx} ? \mathrm{RId}={ }^{2} \pm \& \mathrm{RLId}= \pm{ }_{5} \& \mathrm{PId}=\mu^{3 \mathrm{O}} \mu \& \mathrm{UId}= \pm_{5}-$ .J\&RId=20 [20.10.2016].

Edwards, Derek/Potter, Jonathan (2005): "Discursive psychology, mental states and descriptions”. In: te Molder, Hedwig F./Potter, Jonathan (eds.): Conversation and Cognition. Cambridge, Cambridge University Press: 241-259.

Eichhorn, Kristen (2008): "Soliciting and providing social support over the Internet: An investigation of online eating disorder support groups". Journal of Computer-Mediated Communication 14: 67-78. doi: 10.1111/j.1083-6101.2008.01431.x.

Garfinkel, Harold (1967): Studies in Ethnomethodology. Englewood Cliffs/NJ: Prentice-Hall.

Georgakopoulou, Alexandra (2007): Small Stories, Interaction and Identity. Amsterdam/Philadelphia: Benjamins.

Giles, David/Stommel, Wyke/Paulus, Trena/Lester, Jessica/Reed, Darren (2015): "Microanalysis of online data: The methodological development of 'digital CA"'. Discourse, Context \& Media 7: 45-51. doi: 10.1016/j.dcm.2014.12.002.

Gill, Virginia Teas (2005): "Patient 'demand' for medical interventions: Exerting pressure for an offer in a primary care clinic visit". Research on Language and Social Interaction 38/4: 451-479. doi: 10.1207/s15327973rlsi3804_3. 
Gill, Virginia/Maynard, Douglas (2006): “Explaining illness: Patients' proposals and physicians' responses". In: Heritage, John/Maynard, Douglas W. (eds.): Communication in Medical Care: Interaction Between Primary Care Physicians and Patients. Cambridge, Cambridge University Press: 115-150.

Halkowsky, Timothy (2006): "Realizing the illness: Patients' narratives of symptom discovery". In: Heritage, John/Maynard, Douglas W. (eds.): Communication in Medical Care: Interaction Between Primary Care Physicians and Patients. Cambridge, Cambridge University Press: 86-114.

Hamilton, Heidi E. (1998): "Reported speech and survivor identity in online bone marrow transplantation narratives". Journal of Sociolinguistics 2: 53-67. doi: 10.1111/14679481.00030.

Hamilton, Heidi E. (2004): "Symptoms and signs in particular: The influence of the medical concern on the shape of physician-patient talk". Communication \& Medicine 1/1: 59-70. doi: 10.1515/come.2004.006.

Harrison, Sandra/Barlow, Julie (2009): "Politeness strategies and advice-giving in an online arthritis workshop". Journal of Politeness Research 5/1: 93-111. doi: 10.1515/ JPLR.2009.006.

Have, Paul ten (2001): "Lay diagnosis in interaction". Text 21/1: 251-260. doi: 10.1515/ text.1.21.1-2.251.

Have, Paul ten (2005): "The notion of the member is at the heart of the matter: On the role of knowledge in ethnomethodological inquiry". Historical Social Research 30/1: 28-53.

Hegedüs, Laszlo (s. a.). For lavt stofskifte (Myxфdem). www.netdoktor.dk/sygdomme/ fakta/stofskiftelavt.htm [18.05.2017].

Heritage, John/Maynard, Douglas W. (eds.) (2006): Communication in Medical Care: Interaction between Primary Care Physicians and Patients. Cambridge: Cambridge University Press.

Heritage, John/Robinson, Jeffrey D. (2006): "Accounting for the visit: Giving reasons for seeking medical care". In: Heritage, John/Maynard, Douglas W. (eds.): Communication in Medical Care: Interaction between Primary Care Physicians and Patients. Cambridge, Cambridge University Press: 48-85.

Herring, Susan (2007): "A faceted classification scheme for computer-mediated discourse". Language@Internet 4: article 1.

Hilbert, Richard A. (1984): "The acultural dimensions of chronic pain: Flawed reality construction and the problem of meaning". Social Problems 31/4: 365-378. doi: 10.2307/ 800384.

Hilbert, Richard A. (1995): "Garfinkel's recovery of themes in classical sociology". Human Studies 18: 157-175. doi: 10.1007/BF01323208.

Hutchby, Ian/Woofitt, Robin (2008): Conversation Analysis. Cambridge: Polity.

Jackson, Jean (1994): "Chronic pain and the tension between the body as subject and object". In: Csordas, Thomas J. (ed.): Embodiment and Experience: The Existential Ground of Culture and Self. Cambridge, Cambridge University Press: 201-228.

Jefferson, Gail (1988): “On the sequential organization of troubles-talk in ordinary conversation”. Social Problems 35/4: 418-441. 
Kessing, Lars Vedel (2016, August $16^{\text {th }}$ ): Somatoforme lidelser. www.sundhed.dk/borger/pat ienthaandbogen/psyke/sygdomme/oevrige-sygdomme/somatoforme-lidelser/ [28.06.2017].

Kouper, Inna (2010): “The Pragmatics of peer-advice in a LiveJournal community". Language@Internet 7: article 1.

Labov, William (1972): Language in the Inner City. Philadelphia/PA: University of Pennsylvania Press.

Lamerichs, Joyce/te Molder, Hedwig. F. (2003): “Computer-mediated communication: From a cognitive to a discursive model". New Media \& Society 5/4: 451-473.

Levinson, Stephen C. (2012): “Action formation and ascription”. In: Sidnell, Jack/Stivers, Tanya (eds.): The Handbook of Conversation Analysis. Malden, Wiley \& Sons: 101-130.

Madsen, Karina Søby (2017, January): Kan litteratur bruges som medicin? http://videnskab.dk/naturvidenskab/kan-litteratur-bruges-som-medicin [20.05.2017].

Meredith, Joanne/Potter, Jonathan (2014): "Conversation analysis and electronic interactions: Methodological, analytic and technical considerations". In: Lim, Hwee Ling/Sudweeks, Fay (eds.): Innovative Methods and Technologies for Electronic Discourse Analysis. Hershey, Information Science Reference: 370-393.

Morrow, Phillip (2006): "Telling about problems and giving advice in an Internet discussion forum: Some discourse features”. Discourse Studies 8/4: 531-548. doi: 10.1177/ 1461445606061876.

Myrendal, Jenny (2015): Word Meaning Negotiation in Online Discussion Forum Communication. Unpublished $\mathrm{PhD}$ thesis. University of Gothenburg.

Pomerantz, Anita (1986): "Extreme case formulations: A way of legitimizing claims". Human Studies 9/2: 219-229. doi: 10.1007/BF00148128.

Rathje, Marianne (2013): „Dropper lige subjektet. Subjektellipser i kommentatfeltet på ekstrabladet.dk“. In: Borchmann, Simon/Hougaard, Tina Thode/Widell, Peter/Togeby, Ole/Schoonderbeek Hanse, Inger (eds.): Gode ord er bedre end guld. Festskrift til Henrik Jørgensen. Aarhus, Aarhus Universitet: 399-414.

Reed, Darren (2001): “'Making conversation': Sequential integrity and the local management of interaction on Internet newsgroups". In: Sprague, Ralph H. (ed.): Proceedings of the 34th Annual Hawaii International Conference on System Sciences. Los Alamitos, IEEE Computer Society.

Richardson, Kay P. (2003): "Health risks on the internet: Establishing credibility on line". Health, Risk and Society 5/2: 171-184. doi: 10.1080/1369857031000123948.

Rudolf von Rohr, Marie-Térèse (2017): “'If you start again, don't worry. You haven't failed' Relapse talk and motivation in online smoking cessation". Linguistik Online 87/8: 87-105. doi: 10.13092/lo.87.4174.

Sacks, Harvey (1992a): “April 24: Second stories”. In: Sacks, Harvey: Lectures on Conversation. Vol. 1. Ed. by Gail Jefferson. Oxford, Basil Blackwell: 764-772.

Sacks, Harvey (1992b): "Lecture 4: Story teller as 'witness"”. In: Sacks, Harvey: Lectures on Conversation. Vol 2. Edited by Jefferson Gail; with an introduction by Schegloff, Emanuel A. Oxford, Blackwell: 242-248.

Sacks, Harvey/Schegloff, Emanuel. A./Jefferson, Gail (1974): “A simplest systematics for the organization of turn-taking for conversation”. Language 50/4: 696-735. doi: 10.2307/ 412243. 
Schegloff, Emanuel A. (2007a): "Categories in action: Person-reference and membership categorization”. Discourse Studies 9/4: 433-461. doi: 10.1177/1461445607079162.

Schegloff, Emanuel A. (2007b): "A tutorial on membership categorization". Journal of Pragmatics 39/3: 462-482. doi: 10.1016/j.pragma.2006.07.007.

Sidnell, Jack/Stivers, Tanya (eds.) (2012): The Handbook of Conversation Analysis. Malden: Wiley \& Sons.

Smithson, Janet/Sharkey, Siobhan/Hewis, Elaine/Jones, Ray/Emmens, Tobit/Ford, Tamsin/Owens, Christabel (2011): "Problem presentation and responses on an online forum for young people who self-harm”. Discourse Studies 13/4: 487-501. doi: 10.1177/ 1461445611403356.

Sneijder, Petra/te Molder, Hedwig F. (2004): “'Health should not have to be a problem': Talking health and accountability in an internet forum on veganism". Journal of Health Psychology 9/4: 599-616. doi: 10.1177/1359105304044046.

Sneijder, Petra/te Molder, Hedwig F. (2005): "Moral logic and logical morality: Attributions of responsibility and blame in online discourse on veganism". Discourse \& Society 16/5: 675-696. doi: 10.1177/0957926505054941.

Stommel, Wyke (2009): Entering an Online Support Group on Eating Disorders: A Discourse Analysis. Amsterdam: Rodopi.

Stommel, Wyke/Koole, Tom (2010): "The online support group as a community: A microanalysis of the interaction with a new member". Discourse Studies 12/3: 357-378. doi: $10.1177 / 1461445609358518$.

Thorhauge, Claus (2015, December $\left.6^{\text {th }}\right)$ : Patienter uden diagnose er også syge. www.aoh.dk/ artikel/patienter-uden-diagnose-er-ogs-syge [28.06.2017].

Thurnherr, Franziska/Rudolf von Rohr, Marie-Thérèse/Locher, Miriam A. (2016): “The functions of narrative passages in three written online health contexts". Open Linguistics 2: 450-470. doi: 10.1515/opli-2016-0024.

Wade, Derick T./Halligan, Peter W. (2004): "Do biomedical models of illness make for good healthcare systems?”. British Medical Journal 329: 1398-1401. doi: 10.1136/bmj.32 9.7479.1398.

Werner, Anne/Malterud, Kirsti (2003): "It is hard work behaving as a credible patient: Encounters between women with chronic pain and their doctors". Social Science \& Medicine 57/8: 1409-1419. doi: 10.1016/S0277-9536(02)00520-8.

Yuill, Chris/Crinson, Iain/Duncan, Eilidh (2010): Key Concepts in Health Studies. London: Sage.

Zola, Irving K. (1964): "Illness behavior of the working class: Implications and recommendations". In: Shostak, Arthur/Gomberg, William (eds.): Blue Collar World. Englewood Cliff/NJ, Prentice Hall: 350-361.

Zola, Irving K. (1973): "Pathways to the doctor: From person to patient". Social Science and Medicine 7/9: 677-689. doi: 10.1016/0037-7856(73)90002-4.

\section{Bionote}

Elisabeth Muth Andersen is assistant professor in Danish language and communication at the Department of Language and Communication, University of Southern Denmark, and is a member of the research center Social Practices and Cognition, the research group Digital In- 
teraction and the international network Microanalysis Of Online Data (MOOD). Her research focuses on language use and social interaction investigated by using ethnomethodological conversation analysis (EMCA), membership categorization analysis (MCA) and discursive psychology. Elisabeth Muth Andersen holds a PhD from 2015 which explores micro-analytic methodologies used on the analysis of online health communication (Andersen 2015) and has since then conducted research on digital interaction (Andersen in press) and on interactions involving people with aphasia and people with dementia in everyday and institutional settings (Andersen/Isaksen 2017). 